Rizqy Aji Nugroho

2301912776

\title{
Managing digital transformation
}

Transformasi digital sekarang menjadi faktor penting dalam aktivitas kita sehari-hari. Ini adalah proses menciptakan proses baru atau yang telah diperbarui menggunakan teknologi digital untuk memenuhi harapan pelanggan dan untuk memenuhi kebutuhan bisnis yang berubah. Dalam dunia bisnis, kepuasan pelanggan adalah tujuan utama dari setiap organisasi. Layanan digital memainkan peran penting, karena pelanggan mengharapkan solusi yang bernilai tambah, cepat dan mudah untuk masalah mereka. Transformasi digital membuat lebih banyak data tersedia dan menggunakan teknik yang berbeda untuk memenuhi harapan pelanggan.

Pengurangan biaya teknologi digital dan peningkatan pendidikan digital telah secara radikal mengubah lanskap persaingan dunia modern. Pikirkan sejenak tentang perusahaan Anda sendiri. Jika semua perangkat lunak tiba-tiba dihapus dari bisnis Anda, apa yang tersisa? Pembersih jendela tidak akan dapat beriklan di Facebook atau Google. Akuntan akan kembali ke buku besar manual. Anda tidak akan lagi memiliki kontak langsung dengan pelanggan Anda melalui Twitter. Singkatnya, sebagian besar bisnis dari berbagai ukuran akan runtuh.

Bisnis Anda adalah bisnis perangkat lunak. Tanpa perangkat lunak Anda, bisnis Anda akan berhenti menjadi kekuatan kompetitif di pasar. Oleh karena itu, keberhasilan mengelola transformasi digital sangat penting untuk kelangsungan bisnis Anda.

Digital Transformation Comes Down to Talent in 4 Key Areas

\section{Technology}

Dari Internet of Things, ke blockchain, ke data lake, hingga kecerdasan buatan, potensi mentah dari teknologi yang muncul sangat mengejutkan. Dan sementara banyak di antaranya menjadi lebih mudah digunakan, memahami bagaimana teknologi tertentu berkontribusi pada peluang transformasional, mengadaptasi teknologi itu dengan kebutuhan spesifik bisnis, dan mengintegrasikannya dengan sistem yang ada sangatlah kompleks. Masalah rumit, sebagian besar perusahaan memiliki utang teknis yang sangat besar - teknologi warisan tertanam yang sulit diubah. Anda hanya dapat menyelesaikan masalah ini dengan orang-orang yang memiliki kedalaman dan keluasan teknologi, dan kemampuan untuk bekerja bahu-membahu dengan bisnis.

\section{Data}

Kenyataan yang disayangkan adalah bahwa di banyak perusahaan saat ini sebagian besar data tidak memenuhi standar dasar, dan kerasnya transformasi memerlukan kualitas data dan analitik yang jauh lebih baik. Transformasi hampir pasti melibatkan pemahaman jenis baru data tidak terstruktur (misalnya, gambar kerusakan mobil yang disediakan oleh pengemudi), sejumlah besar data di luar perusahaan Anda, memanfaatkan data kepemilikan, dan mengintegrasikan semuanya bersamasama, sambil membuang sejumlah besar data yang belum pernah (dan tidak akan pernah) digunakan. Data menyajikan paradoks yang menarik: Sebagian besar perusahaan tahu bahwa data itu penting dan mereka tahu kualitasnya buruk, namun mereka menyia-nyiakan sumber daya yang 
sangat besar dengan gagal menempatkan peran dan tanggung jawab yang tepat pada tempatnya. Mereka sering menyalahkan fungsi TI mereka untuk semua kegagalan ini.

Seperti halnya teknologi, membutuhkan bakat dengan keluasan dan kedalaman data yang luar biasa. Yang lebih penting adalah kemampuan untuk meyakinkan sejumlah besar orang di garis depan organisasi untuk mengambil peran baru sebagai pelanggan data dan pembuat data. Ini berarti memikirkan dan mengomunikasikan data yang mereka butuhkan sekarang dan data yang mereka perlukan setelah transformasi. Ini juga berarti membantu pekerja garis depan untuk meningkatkan proses kerja dan tugas mereka sendiri sehingga mereka membuat data dengan benar.

\section{Process}

Transformasi membutuhkan pola pikir ujung ke ujung, pemikiran ulang tentang cara untuk memenuhi kebutuhan pelanggan, koneksi aktivitas kerja yang lancar, dan kemampuan untuk mengelola lintas silo di masa mendatang. Orientasi proses secara alami cocok dengan kebutuhan ini. Tetapi banyak yang menemukan manajemen proses - secara horizontal, melintasi silo, dan berfokus pada pelanggan — sulit untuk didamaikan dengan pemikiran hierarkis tradisional. Akibatnya, konsep yang kuat ini telah merana. Tanpa itu, transformasi direduksi menjadi serangkaian peningkatan bertahap — penting dan bermanfaat, tetapi tidak benar-benar transformatif.

Dalam membangun bakat di domain ini, cari kemampuan untuk "menggembalakan kucing" — menyelaraskan silo ke arah pelanggan untuk meningkatkan proses yang ada dan merancang yang baru, dan rasa strategis untuk mengetahui kapan peningkatan proses tambahan cukup dan kapan rekayasa ulang proses radikal diperlukan.

\section{Organizational Change Capability}

Dalam domain ini menyertakan kepemimpinan, kerja tim, keberanian, kecerdasan emosional, dan elemen manajemen perubahan lainnya. Untungnya, banyak yang telah ditulis tentang domain ini selama bertahun-tahun, jadi kami tidak akan mengulasnya di sini, selain untuk mencatat bahwa siapa pun yang bertanggung jawab atas transformasi digital harus berpengalaman di bidang ini. Sementara, kami tidak memiliki bukti kuat untuk mendukung hal ini, tampaknya mereka yang tertarik pada teknologi, data, dan proses cenderung tidak merangkul sisi manusia dari perubahan. Tentu saja, dalam rekomendasi kami di atas, kami telah mendesak para pemimpin untuk mencari mereka yang memiliki keterampilan orang yang sangat baik. Jika Anda tidak dapat menemukannya, alternatif yang baik adalah menempatkan beberapa "orang ungu", mereka yang mampu bekerja di kedua sisi, di tim transformasi.

Beberapa faktor yang mempengaruhi organisasi untuk meningkatkan kelincahan organisasi, seperti persaingan produk, kemajuan teknologi, dan keunggulan kompetitif. Kemajuan teknologi memaksa organisasi untuk mengadopsi praktik kelincahan perusahaan untuk meningkatkan efektivitas perusahaan. Teknologi informasi diperlukan bagi organisasi untuk mengadopsi tren teknologi terkini. Kemampuan organisasi mendukung kelincahan organisasi untuk berkembang dalam situasi yang tidak pasti dan perubahan yang dinamis. Sumber daya organisasi, terutama karyawan, harus memiliki keahlian digital di tempat kerja untuk membantu merespons dengan 
cepat perubahan teknologi dan ketidakpastian lingkungan untuk keberlanjutan dan kinerja. Dalam lingkungan yang tidak pasti dan dengan kemajuan teknologi, organisasi harus mengatasi hambatan kinerja untuk mempertahankan keunggulan kompetitif. Hambatan kinerja dan gangguan digital terjadi di seluruh teknologi, masyarakat, dan model bisnis yang berdampak pada datangnya pekerjaan, yang membutuhkan kelincahan dan keahlian digital dari karyawan. Dalam penelitian ini, ada tiga hal baru. Pertama, penelitian tentang digital employee experience merupakan sesuatu yang baru dan baru berkembang dalam beberapa tahun terakhir. Yang kedua dari segi objek penelitian adalah perusahaan dry port. Ketiga, mempelajari dampak pengalaman karyawan digital dan kelincahan karyawan terhadap efektivitas perusahaan dry port.

\section{Dry Port Firm Effectiveness}

Efektivitas Perusahaan adalah konsep sentral dari manajemen organisasi. Efektivitas organisasi adalah kemampuan organisasi untuk bertahan dan mencapai tujuan serta mencukupi secara finansial. Istilah efektivitas organisasi dan kinerja organisasi telah digunakan secara bergantian untuk hasil perusahaan. Definisi efektivitas perusahaan dalam penelitian ini adalah kemampuan organisasi untuk mencapai tujuannya melalui penggunaan sumber daya secara efektif sambil beradaptasi dengan lingkungan eksternal.

Literatur sebelumnya tentang ukuran efektivitas pelabuhan kering berfokus pada dimensi terbatas untuk mengukur kinerja pelabuhan atau area pelabuhan tertentu. Pemilihan indikator didasarkan pada tinjauan literatur yang berbeda dan potensial dan beberapa studi dengan penelitian pelabuhan dan terminal yang mendukung studi ini dengan pengetahuan empirisnya. Pemilihan indikator didasarkan pada tinjauan literatur yang berbeda dan potensial dan beberapa studi dengan penelitian pelabuhan dan terminal.

\section{Relationship Between Digital Employee Experience and Dry Port Firm's Effectiveness}

Pengalaman kerja karyawan melibatkan beberapa faktor, antara lain menemukan makna pekerjaan, berinteraksi, dan menanggapi praktik internal di tempat kerja. Pengalaman kerja karyawan akan menciptakan keterikatan karyawan yang lebih besar, dan karyawan sangat berkomitmen untuk membangun pengalaman yang lebih baik bagi pelanggan dan karyawan lainnya. Ciptakan pengalaman kerja karyawan yang melibatkan komponen manusia dan teknologi digital. Teknologi adalah faktor penting untuk transformasi digital dari pengalaman pengguna. Pengalaman karyawan digital mengintegrasikan teknologi ke dalam titik kontak karyawan yang kritis dan merancang seluruh siklus hidup karyawan dari 'perekrutan hingga pembelajaran' dengan gerakan digital.

Pengalaman digital karyawan muncul dalam digitalisasi di perusahaan dan memberikan pengetahuan baru untuk mengatasi masalah dan kebutuhan untuk mencapai efektivitas perusahaan dan mengintegrasikan dan mengkoordinasikan berbagai kegiatan perusahaan. Hal ini kemudian memungkinkan untuk memenuhi kebutuhan staf untuk dianggap sebagai peluang bisnis yang strategis. Dalam bisnis dry port, pengalaman digital karyawan menempatkan orang-orang di pusat operasi bisnis, menyadari bahwa sistem dan proses harus produktif dan menyenangkan. Dan banyak yang menetapkan peran baru untuk memberikan pengalaman karyawan digital. 
Dibutuhkan berbagai format, termasuk manajer saluran digital internal, manajer pengalaman digital, dan tim pengalaman karyawan

Munculnya poin-poin baru, seperti transformasi digital di dunia bisnis, khususnya perusahaan dry port, belakangan ini. Beberapa spesialis setuju bahwa peningkatan profitabilitas dan kelangsungan hidup organisasi pelabuhan kering bergantung pada partisipasi dalam perjalanan transformasi digital tahun depat. Pemimpin yang berorientasi digital harus terus menantang organisasi mereka dan memberikan pengalaman digital kepada karyawan untuk memastikan bahwa perubahan menciptakan keunggulan kompetitif dan efektivitas bagi organisasi.

\section{Relationship Between Employee Agility and Dry port Firm Effectiveness}

Kelincahan adalah kemampuan untuk menjadi kreatif dan mengatasi perubahan tak terduga untuk mencapai tujuan dalam lingkungan bisnis yang dinamis dan menyeimbangkan fleksibilitas dan stabilitas. Agility melihat keterbatasan perubahan dalam keadaan minimal dan merespon setiap perubahan yang mungkin dan tidak terduga, sementara fleksibilitas merespon perubahan yang direncanakan. akuntabilitas dan kelincahan dalam produksi dapat dicapai melalui teknologi canggih di masa lalu. Sementara integrasi komputer dapat memberikan keunggulan kompetitif, mencapai fleksibilitas dalam produksi dan layanan memerlukan pengembangan dan pemeliharaan elemen teknologi tinggi dan sumber daya manusia untuk menghadapi situasi yang tidak terduga. Oleh karena itu, kita harus mengenali peran tenaga manusia dalam mempromosikan kelincahan. Kelincahan sumber daya manusia merupakan salah satu dimensi kelincahan organisasi dalam organisasi untuk mencapai efektivitas perusahaan.

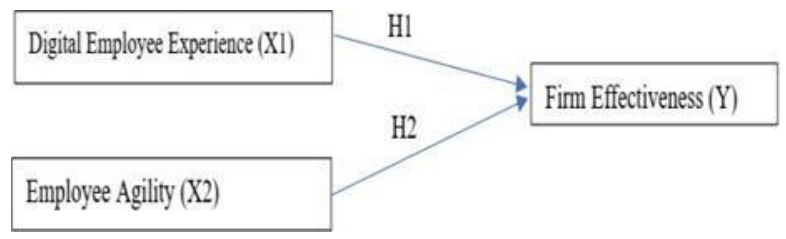

\section{Kesimpulan}

Transformasi digital sekarang menjadi faktor penting dalam aktivitas kita sehari-hari. Ini adalah proses menciptakan proses baru atau yang telah diperbarui menggunakan teknologi digital untuk memenuhi harapan pelanggan dan untuk memenuhi kebutuhan bisnis yang berubah. Dalam dunia bisnis, kepuasan pelanggan adalah tujuan utama dari setiap organisasi. Layanan digital memainkan peran penting, karena pelanggan mengharapkan solusi yang bernilai tambah, cepat dan mudah untuk masalah mereka. Transformasi digital membuat lebih banyak data tersedia dan menggunakan teknik yang berbeda untuk memenuhi harapan pelanggan.

Dengan pengalaman digital karyawan, seperti asisten virtual SDM, mereka dapat membantu dengan kebijakan perusahaan yang diperlukan untuk karyawan, seperti tunjangan, rencana liburan, dan magang di tempat kerja. Mereka dapat menghasilkan surat kerja standar berdasarkan kebutuhan karyawan. Karyawan memiliki hidangan utama untuk asisten ini, yang mendukung perusahaan meningkatkan efektivitas dengan menghemat banyak waktu. Pengalaman digital yang memerlukan Keterlibatan dan kolaborasi dapat memberikan pemahaman yang lebih mendalam tentang pemahaman dan asumsi pekerja bagi perusahaan dan direktur, memungkinkan mereka 
untuk bereaksi sesuai jadwal jika ada adalah masalah yang harus cenderung. Pada intinya, pengalaman karyawan digital mengharuskan perusahaan, terutama Divisi Human Capital, memiliki kemampuan manajemen data yang benar untuk menganalisis dan berkontribusi dalam pengambilan keputusan yang sukses. Seiring dengan banyak sistem informasi sumber daya manusia, perusahaan menawarkan beberapa kali, di mana saja fasilitas bantuan dengan aplikasi, telepon, dan biaya lain yang dikeluarkan untuk kebutuhan karyawan. Pengurangan biaya teknologi digital dan peningkatan pendidikan digital telah secara radikal mengubah lanskap persaingan dunia modern.

Karyawan yang gesit dapat menjadi jawaban yang tepat untuk mencapai efektivitas perusahaan, dan mereka mencoba mengintegrasikan pola pikir dan perilaku yang lebih gesit ke dalam bisnis sehari-hari mereka. Khususnya dalam organisasi pelabuhan kering, langkah menuju kelincahan ini telah terbukti menjadi usaha yang menantang. Untuk memasukkan kelincahan ke dalam budaya mereka, organisasi harus menggunakan strategi yang berbeda untuk mencapai Efektivitas yang Kuat. Sebuah perusahaan dengan karyawan kelincahan yang sukses membutuhkan aspirasi, komitmen, alokasi sumber daya, pengukuran kemajuan, dan penghargaan. Kombinasi dari semua faktor tersebut dapat meningkatkan kelincahan dalam suatu perusahaan. 


\section{Referensi:}

D. H. Syahchari, Lasmy, M. G. Herlina, H. Saroso, D. Sudrajat and H. K. W. Jordaan, "The Influence of Digital Employee Experience and Employee Agility: Do They Boost Firm's Effectiveness?," 2021 International Conference on Information Management and Technology (ICIMTech), 2021, pp. 67-71, doi: 10.1109/ICIMTech53080.2021.9534976.

Saroso, H., Syahchari, D. H., Sudrajat, D., Lasmy, \& Herlina, M. G. (2021). Managing digital transformation dilemma with industrial mapping. Paper presented at the Proceedings of 2021 International Conference on Information Management and Technology, ICIMTech 2021, 165-170. doi:10.1109/ICIMTech53080.2021.9535025 Retrieved from www.scopus.com 